\title{
PIOTR PIOTROWSKI. PORTRET PRAKTYKA KRYTYCZNEJ HISTORII SZTUKI
}

Dorobek badawczy Piotra Piotrowskiego jest znany na świecie. On sam był aktywnym członkiem międzynarodowego środowiska naukowego. Przez całe życie, jednak, pozostał silnie związany z Instytutem Historii Sztuki na Uniwersytecie im. Adama Mickiewicza i z Poznaniem.

W Instytucie Historii Sztuki UAM studiował w latach 1971-1976 i pracował od $1980^{1}$. Edukacja w poznańskiej jednostce w dużym stopniu ukształtowała jego postawę badawczą i podejście do sztuki. W wywiadach i prywatnych rozmowach wskazywał na dwie osoby, starszych kolegów, którzy w tamtym czasie odegrali kluczową rolę - Andrzeja Turowskiego i Jarosława Kozłowskiego.

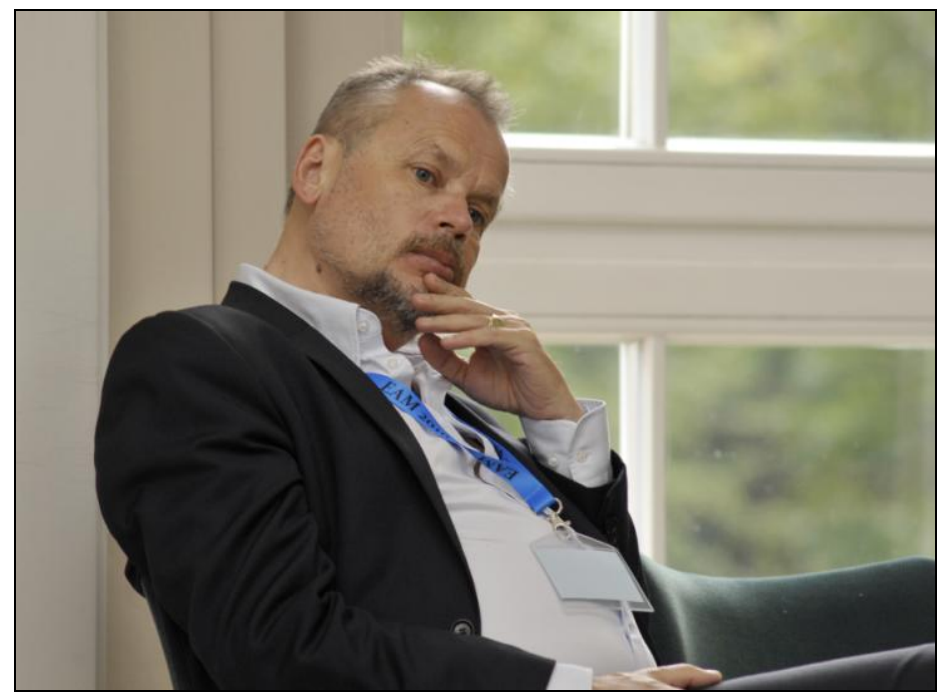

Prof. zw. dr hab. Piotr Piotrowski 1952-2015

1 W latach 1976-78 pracował w Instytucie Kulturoznawstwa na UAM, a w latach 1978-1980 na zlecenie konserwatorów województw zielonogórskiego i leszczyńskiego wykonywał dokumentacje zabytkowych cmentarzy. 
Andrzej Turowski, pracujący jako asystent w IHS UAM, wyrastał wtedy na jedną z najważniejszych osób kształtujących oblicze poznańskiej historii sztuki. Jedną z cech tej ostatniej był duży nacisk kładziony na refleksję metodologiczną ściśle powiązaną z badaniami historycznymi. Ważne w tym środowisku stały się koncepcje semiotyczne, które za atrakcyjne uważał też Piotrowski. Najistotniejsze, jak widać z perspektywy czasu, okazały się jednak wyrastające $\mathrm{z}$ marksistowskich teorii refleksje na temat ideologii i władzy, a także analizy społecznych uwarunkowań funkcjonowania sztuki. Zainteresowanie nimi we wczesnej działalności badawczej Piotrowskiego znalazło wyraz w pracy magisterskiej poświęconej Firmie Portretowej „S.I. Witkiewicz”, której fragmenty zostały opublikowane jako Portrety $i$ społeczeństwo. O Firmie Portretowej „S.I. Witkiewicz”2. Witkiewiczowi poświęcił Piotrowski też swoją pracę doktorską zatytułowaną „Teoria Czystej Formy malarstwa Witkacego w kontekście współczesnych mu postaw artystycznych”, obronioną w 1982 roku i opublikowaną trzy lata później w Wydawnictwie Naukowym $\mathrm{UAM}^{3}$.

Choć konkretne postulaty badawcze Piotrowskiego przez lata ulegały zmianom, to u ich podstawy leżało ukształtowane w latach 70. i wzmocnione na początku lat 80. przekonanie o powiązaniu procesów artystycznych ze społecznymi, a także o konieczności analizy relacji sztuki $\mathrm{z}$ ideologią i władzą. Niebagatelną rolę w ugruntowaniu tego stanowiska odegrały wydarzenia polityczne. Piotrowski zaangażował się w 1984 roku w nielegalną działalność Solidarności, stając się wtedy członkiem redakcji, a także jednym z autorów podziemnego pisma „Obserwator Wielkopolski”. Środowisko z nim związane pełniło wtedy znaczącą rolę opiniotwórczą. Piotrowski w bibliografii swoich publikacji wymienił jedną z „Obserwatora Wielkopolskiego”, wspominając inne „krótkie artykuły publikowane pod rozmaitymi pseudonimami" - przeprowadzony w 1989 roku wywiad ze Stanisławem Barańczakiem zatytułowany Spychamy kulturę na szary koniec ${ }^{5}$. Dotykał on dylematu ważnego w tamtych latach dla wielu działaczy opozycji związanych z kulturą - na ile należy poświęcić się polityce, na ile kulturze. W wyniku opowiedzenia się za tą ostatnią, ale nie wbrew polityce, powstało w poznańskim środowisku w 1985

2 Opublikowane w: Problemy interpretacji dzieła sztuki i jego funkcji społecznych, red. K. Kalinowski, Poznań, Wydawnictwo Naukowe UAM, 1980, s. 154-168.

${ }^{3}$ Metafizyka obrazu. O teorii sztuki i postawie artystycznej Stanistawa Ignacego Witkiewicza, Poznań, Wydawnictwo Naukowe UAM, 1985, s. 130.

${ }^{4}$ www.amu.edu.pl/ piotrpio

5 Spychamy kulturę na szary koniec. Rozmowa ze Stanisławem Barańczakiem, „Obserwator Wielkopolski”, nr 135, Poznań 1989, s. 4-5. 
roku czasopismo „Czas Kultury”. Na początku lat 90. Piotrowski opublikował tam dwa teksty, a w wydającej je oficynie ukazały się jego dwie książki eseistyczne: Dekada (1991) i W cieniu Duchampa. Notatki nowojorskie (1996).

Wtedy, kiedy współpracował z „Obserwatorem Wielkopolskim”, pisał Piotrowski rozprawę habilitacyjną poświęconą awangardzie rosyjskiej. Skupił się w niej na problemie uwikłania artystów w ideologię, na stopniowym odsuwaniu się ich od rzeczywistości, fałszowaniu obrazu rewolucji i angażowaniu w pracę na rzecz reakcyjnej polityki. Ukazała się jako książka zatytułowana Artysta między rewolucją i reakcją. Studium z zakresu etycznej historii sztuki awangardy rosyjskiej w 1993 roku (Poznań, Wydawnictwo Naukowe UAM).

Aktywność historyka sztuki splatała się w tamtym okresie nie tylko z działalnością polityczną i publicystyczną, ale też krytyczną. Dla jej prześledzenia konieczny jest powrót do czasów studiów Piotrowskiego i znajomości z Jarosławem Kozłowskim. Ten poznański artysta w 1971 roku podjął się na krótki czas uczenia studentów Instytutu Historii Sztuki UAM technologii malarskich. Opowiadał im nie tylko o nich, ale też o sztuce współczesnej i aktualnym życiu artystycznym, co zaowocowało wspólną inicjatywą - utworzeniem galerii Akumulatory. Piotrowski aktywnie uczestniczył w działalności galerii, a zorganizowana tam wystawa Henri Chopina była tematem jego pierwszego tekstu krytycznego opublikowanego w 1975 roku w czasopiśmie „Nurt”6. Kozłowski, który wraz z Andrzej Kostołowskim od 1971 roku realizował projekt mail-artowy NET, nawiązał rozbudowane kontakty międzynarodowe. Dzięki temu współpracujący z nim studenci mieli okazję poznać wielu twórców z Europy Wschodniej, ale też, choć oczywiście w mniejszym stopniu, Ameryki Południowej. Piotrowski powracał potem do tego doświadczenia wielokrotnie przy różnych okazjach. W 1993 roku zorganizował w Muzeum Narodowym w Poznaniu wystawę „Galeria odNOWA, 1964-1969” poświęconą inicjatywie, na doświadczeniu której wyrastała działalność Akumulatorów, a w 1997 przygotował ekspozycję monograficzną Jarosława Kozłowskiego. Swój ostatni projekt badawczy poświęcony budowaniu porównawczej globalnej historii sztuki rozpoczął od zestawienia działalności NETu z aktywnością wybranych artystów z Ameryki Południowej7.

${ }^{6}$ Henri Chopin w Galerii Akumulatory 2, w: „Nurt”, 1975, 8, s. 34-35.

${ }^{7}$ Globalny NETwork. W stronę porównawczej historii sztuki, „Artium Quaestiones”, 2014, XXV, s. 139-175. The Global NETwork: An Approach to Comperative Art History, w: "Circulations in the Global History of Art", Thomas DaCosta Kaufmann, Catherine Dossin, Béatrice Joyeux-Prunel (eds.), Ashgate, 2015, s. 149-165. 
Wyrazem zaangażowania $\mathrm{w}$ działalność środowiska artystycznego i potrzeby jego komentowania była książka Dekada: o syndromie lat siedemdziesiatych, kulturze artystycznej, krytyce, sztuce - wybiórczo $i$ subiektywnie publikowana w 1991 roku. Piotrowski z niezwykłą pasją poddał w niej bezpardonowej krytyce szereg bezwartościowych według niego zjawisk artystycznych. Niewielka książeczka wywołała w środowisku niezwykły ferment i przez wiele lat wzbudzała żywe emocje. Sam autor miał do niej dystans. Tłumaczył w jednym z wywiadów: „Nie chcę się rzecz jasna wycofać z przedstawionych tam opinii. $\mathrm{Z}$ dzisiejszej perspektywy wydają się jednak dość przerysowane, część z nich znacznie zweryfikowałem. Ale była to prawdziwie szczera wypowiedź, wynikająca z pewnego rozdrażnienia tamtym czasem, rozmyciem dyskusji, przyzwoleniem na niemal wszystko w sztuce. To mnie drażniło"s. Ta książka jest wyjątkiem w dorobku Piotrowskiego, w tym sensie, że w innych publikacjach nie znajdziemy tak negatywnych opinii na temat poszczególnych artystów i ich dzieł. Krytyczną pasję kierował od tamtej pory w stronę mechanizmów czy przepisów uniemożliwiających swobodną, krytyczną działalność. W odniesieniu do artystów skupił się na krytyce pozytywnej przejawiającej się we wspieraniu tych twórców, których postawy były mu bliskie.

Pracując przez kilka lat w Muzeum Narodowym w Poznaniu na stanowisku kierownika działu sztuki współczesnej (1992-1997), miał możliwość zaprezentowania twórczości bliskich sobie artystów w medium wystawy. Obok wspomnianych już ekspozycji, przygotował pokazy indywidualne Jerzego Beresia (1995) i Zofii Kulik (1999). Okres jego zatrudnienia $\mathrm{w}$ historii poznańskiego Muzeum Narodowego w Poznaniu był wyjątkowy, bo jedyny, kiedy sztuka współczesna zajmowała w jego programie znaczącą rolą. Nie trwał on zbyt długo, gdyż po tym jak wystawę Kulik ocenzurował ówczesny dyrektor Muzeum, Konstanty Kalinowski, Piotrowski zrezygnował z pracy. Nie zakończyło to bynajmniej współpracy między nim a bliskimi mu twórcami, należałoby do nich jeszcze dodać przynajmniej Krzysztofa Wodiczkę i Zbigniewa Liberę, do katalogów których regularnie pisał teksty ${ }^{9}$

Istotna zmiana w działalności naukowej Piotrowskiego nastąpiła na przełomie lat 80. i 90. Wiązała się w dużej mierze z podróżami badaw-

${ }^{8}$ Miłość do emancypacji. O warsztacie i zaangażowaniu badacza-humanisty $z$ Piotrem Piotrowskim rozmawiaja Luiza Nader, Katarzyna Bojarska i Adam Mazur, „Widok. Teorie i praktyki kultury wizualnej”, 3, 2013, www.widok.ibl.waw.pl.

9 Po śmierci Piotrowskiego niektórzy z tych twórców, związani z Fundacją Profile, przygotowali wystawę dedykowaną jego pamięci - Sztuka wedtug polityki, Fundacja Profile, Warszawa, 31.07-19.09.2015. 
czymi, spotkanymi w czasie ich trwania ludźmi i nowymi lekturami. Kluczowe znaczenie odegrały wyjazdy na stypendia do Stanów Zjednoczonych, kolejno: The Kościuszko Foundation Research Grant na pobyt studyjny w Nowym Jorku (1989), Ailsa Mellon Bruce Senior Fellow w Center for Advanced Study in the Visual Arts w National Gallery of Art w Waszyngtonie (1989/90), J.P. Getty Fellow na Columbia University w Nowym Jorku (1994). Jednym z owoców tych wyjazdów była książka W cieniu Duchampa. Notatki nowojorskie (Obserwator 1996). Recepcja tego, co się wówczas działo w amerykańskiej sztuce i jej teorii znacznie wyraźniejsza była jednak w dydaktyce i pracy badawczej. Piotrowskiego szczególnie pociągały refleksje rozwijane w środowisku związanym z czasopismem „October”, przez takie osoby jak Rosalind E. Krauss, Douglas Crimp, czy Hal Foster. Skupiali się oni na sztuce nowoczesnej i aktualnej oraz teorii, głównie tekstach francuskich filozofów, socjologów i psychoanalityków adoptowanych do analizy zjawisk z obszaru współczesnej kultury. Było to środowisko intelektualnie stymulujące, politycznie zaangażowane, lewicowe ${ }^{10}$. Taki profil bardzo odpowiadał Piotrowskiemu, który włożył dużo wysiłku w prezentowanie tej postawy badawczej i prac naukowych jej reprezentantów w Polsce, przywołując ich w swoich tekstach i na zajęciach, organizując wykłady i drukując przekłady artykułów. Miał znaczący wpływ na wybór tłumaczeń ukazujących się w roczniku Instytutu Historii Sztuki UAM „Artium Quaestiones”, przede wszystkim w latach 1997-2009, kiedy był jego współredaktorem ${ }^{11}$. Za jego sprawą ukazały się też w Polsce przekłady książek brytyjskich badaczy o podobnej orientacji: Sposoby widzenia Johna Bergera (Rebis, 1997, tłum. Mariusz Bryl) i Akt kobiecy. Sztuka, obscena i seksualność Lyndy Nead (Rebis 1998, tłum. Ewa Franus). Za sprawa tych między innymi działań w drugiej połowie lat 90. poznańska historia sztuki raz jeszcze stała się miejscem, gdzie najnowsze nurty metodologiczne były dyskutowane i adaptowane $\mathrm{w}$ pracach badawczych. W tamtym też okresie studiowali w IHS ci, których dziś wymienia się jako uczniów Piotrowskiego i jego kontynuatorów, m.in. Izabella Kowalczyk, Paweł Leszkowicz, Piotr Bernatowicz, Magdalena Radomska, Jakub Dąbrowski i pisząca te słowa.

10 Używam czasu przeszłego, by podkreślić szczególną rolę tego środowiska właśnie w latach 80. i 90. XX wieku. Czasopismo nadal istnieje, ale dziś nie wydaje się już odgrywać kluczowej roli.

${ }^{11} \mathrm{~W} 2009$ roku ukazał się z jego inicjatywy zbiór tych przekładów: Perspektywy wspótczesnej historii sztuki. Antologia przekładów „Artium Quaestiones”, red. M. Bryl, P. Juszkiewicz, P. Piotrowski, W. Suchocki, Poznań: Wydawnictwo Naukowe UAM. Stanowił on, co wyraźnie widać z perspektywy czasu zamknięcie okresu intensywnej pracy Piotrowskiego na rzecz Instytutu Historii Sztuki UAM, w tym „Artium Quaestiones”. 
Zainteresowanie amerykańską historią sztuki wcale nie oznaczało wybrania prac tamtejszych artystów na temat swoich badań. Piotrowski pisał wtedy książkę o polskiej sztuce czasu PRL-u, która ukazała się w 1999 roku jako Znaczenia modernizmu. W stronę historii sztuki polskiej po 1945 roku. Raz jeszcze - jak w latach 70. - inspirujące okazały się dla niego z jednej strony dyskusje metodologiczne, z drugiej to, co działo się na polskiej scenie artystycznej. To był szczególny czas - okres narodzin i rozwoju tego, co później okrzyknięto „sztuką krytyczną”. Piotrowski stał się jednym z adwokatów twórców reagujących, często $\mathrm{w}$ formie wywołującej kontrowersje, na społeczno-ekonomiczno-polityczne zmiany mające miejsce w czasie transformacji ustrojowej. Podobną miarą mierzył ich i tych, którzy tworzyli w czasie PRL-u. Była to miara „krytyczności” stopnia i sposobu, w jaki twórca swoją sztuką kontestował władzę, w różny sposób rozumianą.

Polska sztuka okresu PRL-u stała się punktem wyjścia do interpretacji twórczości powstającej w całym tzw. bloku wschodnim. Początek aktywności Piotrowskiego na tym polu datuje się na drugą połowę lat 90 ., kiedy realizował grant Komitetu Badań Naukowych przyznany na projekt „Modernizm i totalitaryzm. Sztuka Europy Środkowo-Wschodniej, 1953-1989" (1997-2000). Uczestniczył też wtedy w pracach międzynarodowych zespołów przygotowujących wystawy poświęcone dwudziestowiecznej sztuce Europy Środkowej i Wschodniej, jednej zorganizowanej w Bonn („Europa, Europa”, kuratorzy: Ryszard Stanisławski i Andrzej Turowski 1994), drugiej w Sztokholmie i Berlinie („After the Wall. Art and Culture in Post-Communist Europe", kuratorka: Bojana Pejić, 1999-2000). Od tego czasu był członkiem, i jak podkreślają jego współpracownicy, siłą napędową wielu projektów badawczych związanych z tym obszarem tematycznym.

Jego autorskie interpretacje twórczości powstającej w komunistycznej Europie przedstawione zostały w najważniejszej książce Piotrowskiego - Awangarda $w$ cieniu Jalty. Sztuka i awangarda $w$ Europie Środkowo-Wschodniej. 1945-1989 wydanej w 2005 roku (Poznań: Rebis). Olbrzymie znaczenie tej publikacji polega przede wszystkim na tym, że po raz pierwszy jakiś badacz zaproponował bardzo szerokie spojrzenie na sztukę czasów komunizmu w Europie Środkowej i Wschodniej, w którym, z jednej strony, pokazuje się specyfikę tego regionu, z drugiej zaś, akcentuje różnice między jego poszczególnymi częściami. Podstawą metodologiczną do zawartych $\mathrm{w}$ tej książce analiz jest opracowana przez Piotrowskiego koncepcja „horyzontalnej historii sztuki”. To perspektywa krytyczna wobec hierarchicznej, uniwersalizującej narracji historyczno-artystycznej uprzywilejowującej centrum i jego system wartości. Nie podważa ona nie- 
zwykle ważnej roli, jaką pełnią pewne ośrodki, ale redefiniuje relację między nimi a tymi, które mają status prowincji. Istotne staje się tworzenie wielu równorzędnych narracji, w których kluczową rolę odgrywa lokalna perspektywa. Usytuowanie na marginesie - w jego wypadku: w Poznaniu - stało się w tej koncepcji nie wadą, a ważną cechą pozycji badawczej.

Piotrowski należał do tych naukowców, których można określić mianem wizjonerów. Odwiedzał kraje, o których pisał, rozmawiał z artystami i krytykami, zbierał materiały, ale praca nad ich drobiazgowym opracowaniem nie była jego żywiołem. Zapytany o to w jednym $\mathrm{z}$ wywiadów, odpowiedział trochę żartem: „Jestem uczulony na kurz i w archiwach nie czuję się najlepiej"12. Ważniejsze dla niego było wykreślenie wyrazistego obrazu, który pokazuje mechanizmy funkcjonowania opisywanych zjawisk. Uwypuklenie tego, co pozostawało niezauważone, a zwłaszcza przemilczane. Stawianie mocnych tez. Można to odnaleźć w Awangardzie $w$ cieniu Jałty, która została doceniona zarówno w kraju, jak i za granicą. W 2006 roku Piotrowski dostał Nagrodę Jana Długosza, rok później Premiera Rady Ministrów, a w 2010 Igor Zabel Award for Culture and Theory. W uzasadnieniu przyznania tej ostatniej pisano między innymi, że: „He is active in setting up a network, as well as disseminating the specific art practices and ideas that originate in the region [Central Eastern Europe - A.J.], outside of the centres. By doing so, Piotr Piotrowski acts as a sort of cultural ambassador"13. Rzeczywiście, dzięki przetłumaczonej na język angielski Awangardzie w cieniu Jałty, ale także bardzo dużej aktywności pisarskiej14 i wykładowej, Piotrowski stał się rozpoznawanym i uznanym na świecie badaczem sztuki Europy Środkowo-Wschodniej. Przy okazji promującym poznański ośrodek badawczy. Można by zaryzykować stwierdzenie, że gdziekolwiek jest pisana historia sztuki Europy Środkowo-Wschodniej XX wieku, zwłaszcza jego drugiej połowy, powstaje w dialogu z tekstami Piotrowskiego.

Trudno dzisiaj ocenić, czy taką samą siłę będzie miała opracowana przez niego koncepcja „muzeum krytycznego”. Kiedy zaproponowano mu stanowisko dyrektora Muzeum Narodowego w Warszawie, które zajmował w 2009 i 2010 roku, przygotował program jego działania opierający się na przekonaniu, że muzeum powinno podejmować problemy, jakimi żyje społeczeństwo i brać udział w debacie społecznej. Piotrowski próbo-

12 Miłość do emancypacji..., op. cit.

$13 \mathrm{http} / / /$ www.igorzabel.org/en/award/award-2010

${ }_{14}$ Między innymi Agorafilia. Sztuka i demokracja $w$ postkomunistycznej Europie, Poznań: Rebis, 2010, s. 300; wydanie angielskie: Art and Democracy in Post-Communist Europe, London: Reaktion Books, 2012, s. 312. 
wał zastosować koncepcje dotyczące instytucji muzealnej wypracowywane w muzeach sztuki nowoczesnej i współczesnej w muzeum mającym status narodowego. Flagową dla jego programu wystawą była ekspozycja poświęcona wątkom homoerotycznym w sztuce dawnej i współczesnej Ars Homo Erotica ${ }^{15}$, do której przygotowania zaprosił swojego byłego doktoranta, pracownika IHS UAM, dr. Pawła Leszkowicza. Wielu muzealników odniosło się krytycznie do działań Piotrowskiego, albo krytykując koncepcję, albo wyrażając wątpliwości co do możliwości i sposobów jej realizacji. Ten, po utracie poparcia przez Radę Muzeum, zrezygnował z pracy w Muzeum, ale nie z wypracowanej przez siebie koncepcji. Opublikował książkę Muzeum krytyczne (Poznań: Rebis, 2011), która przybliżała ideę i opisywała próbę jej wprowadzenia w Muzeum Narodowym w Warszawie. W 2015 roku wyszła też monografia zbiorowa, zredagowana wspólnie z Katarzyną Murawską-Muthesius, współpracującą z Piotrowskim jako wicedyrektor Muzeum Narodowego w Warszawie, zatytułowana From Museum Critique to the Critical Museum (Ashgate 2015). Grono międzynarodowych praktyków i badaczy muzeów ustosunkowało się do koncepcji Piotrowskiego, prezentując swoje sposoby na to, by uczynić muzeum instytucją krytyczną.

Piotrowski pracował ostatnio nad projektem zatytułowanym Globalizowanie sztuki Europy Wschodniej po 1945 roku. Jego celem było spojrzenie na poszczególne zjawiska artystyczne rozwijające się w tym obszarze przez pryzmat podobnych, mających miejsce $\mathrm{w}$ innych regionach świata. Nie miał ambicji napisania monografii, która objęłaby wszystko. Włączał się w dyskusje nad możliwością pisania nieimperialnej światowej historii sztuki z propozycją narracji konstruowanej z konkretnego miejsca, w jego wypadku Europy Środkowo-Wschodniej, a konkretniej - Poznania. Konsekwentnie realizował tym samym postulat usytuowanej wiedzy, rozszerzając stopniowo obszar, którego dotyczyły jego studia. Tym razem badania, o komparatystycznym charakterze, miały obejmować Polskę, Argentynę, Indie, Kubę, Kenię i RPA. Nie wszędzie zdążył dotrzeć. Jednak, między innymi dzięki dobrze opracowanemu i konsekwentnie realizowanemu planowi badawczemu, Piotrowski na bieżąco interpretował pozyskane materiały. Rodzina podjęła decyzję o publikacji tekstu w takiej postaci, w jakiej był on w momencie śmierci Autora. Ukaże się nakładem wydawnictwa Rebis, z którym od wielu lat współpracował. Ukaże się też redagowany przez niego tom z materiałami z międzynarodowej konferencji „Sztuka Europy Wschodniej widziana z globalnych per-

15 Ars Homo Erotica, 11.06.-05.09.2010, kurator wystawy: Paweł Leszkowicz, Muzeum Narodowe w Warszawie. 
spektyw: przeszłość i teraźniejszość”, którą zorganizował w Galerii Labirynt w Lublinie w październiku 2014 roku16.

Objęcie stanowiska dyrektora Muzeum Narodowego w Warszawie w 2009 roku wiązało się z osłabieniem aktywności Piotrowskiego na rzecz poznańskiego Instytutu Historii Sztuki. Już rok wcześniej przestał pełnić funkcję dyrektora tej jednostki17, w 2009 roku zrezygnował także z kierowania Zakładem Historii Sztuki Nowoczesnej. Cały czas prowadził jednak zajęcia, głównie cieszące się popularnością wykłady monograficzne, seminaria ogólne i magisterskie. W ostatnich latach zaangażował się też w dyskusję o kształcie uniwersytetu. Jak wiele innych osób, także jego niepokoiły zmiany zachodzące $\mathrm{w}$ szkolnictwie wyższym, przede wszystkim technicyzacja, korporyzacja i komercjalizacja systemu akademickiego ${ }^{18}$. Przyczyniały się one, według niego, do niemożliwości realizowania głównego zadania uniwersytetu, jakim jest nauka krytycznego myślenia. Piotrowski nie poprzestawał na utyskiwaniu. Zachęcał do aktywnego oporu, który sam realizował, odmawiając przygotowania sylabusów w formie wymaganej przez władze UAM i publicznie na łamach „Życia Uniwersyteckiego" podejmując polemikę z jego autorkami ${ }^{19}$. Podobnie było w 2007 roku, kiedy nie tylko krytykował tzw. ustawę lustracyjną, ale i odmówił podpisania oświadczenia lustracyjnego.

Piotrowski uważał, że nieodłącznym elementem bycia humanistą jest uczestniczenie w debacie publicznej. Był przekonany o powiązaniu sztuki, jej instytucji, ale także jej badaczy, a więc też uniwersytetu, z przestrzenią publiczną. Podkreślał wielokrotnie, że demokracja nie jest nam dana raz na zawsze i trzeba cały czas działać na rzecz jej utrzymania i ulepszenia. Jednym z najważniejszych sposobów działania jest krytyczne myślenie i oparte na nim działanie, praktykowanie postawy krytycznej. To stanowiło dla niego główne kryterium oceny różnych zjawisk. Przede wszystkim cenił sobie jednak spór i w możliwości jego prowadzenia widział wartość demokracji. Nigdy nie przestał zajmować wyraźnej pozycji, ale też szanować osób, które były odmiennego zdania. Głośno protestował, kiedy oceny dorobku naukowego ulegały wpływom konfliktów światopoglądowych. Bronił też wolności słowa, przekonując, że w interesie obywateli jest uznanie prawa do bluźnierstwa, „które nie zawsze jest ele-

${ }^{16}$ Materiały ukażą się pod redakcją Katarzyny Murawskiej-Muthesius, Bojany Pejić i Beate Hock.

17 W latach 1996-1999 były wicedyrektorem, w latach 1999-2009 dyrektorem Instytutu Historii Sztuki UAM.

${ }^{18}$ Róbmy strajk, profesorowie, „Gazeta Wyborcza”, 14-15.06.2014, s. 25.

19 P. Piotrowski, Sylabus - tak, „sylabus” - nie, „Życie Uniwersyteckie”, luty 2014, s. 20. 
ganckie, ale jego obecność jest nieporównanie bardziej bezpieczna niż ograniczenia w tej materii" 20 .

Ostatnim większym wydarzeniem naukowym, w którym miałam okazję uczestniczyć z Piotrem Piotrowskim, było sympozjum „Art in Transfer. Curatorial Practices and Transnational Strategies in the Era of Pop" zorganizowane na Södertörn University w Sztokholmie w listopadzie 2014 roku. Piotr wygłosił tam wykład plenarny. Uczynił to, mimo że już po przyjeździe do Sztokholmu nabawił się zapalenia oskrzeli. „Nie mogę ich przecież zawieść" - powiedział mi, tłumacząc dlaczego pojawił na obradach. Nie wytrzymał na nich zbyt długo. Kiedy toczyły się one bez niego, można było w kuluarach usłyszeć głosy wyrażające żal, że Piotra nie ma, bo on zawsze wprowadza ożywienie, zarówno w dyskusję naukową, jak i spotkania towarzyskie. Tak go postrzegano, i takim zostanie zapamiętany, jako człowiek o niespożytej energii, nietuzinkowy intelektualista i świetny kompan. Redaktorzy tomu z materiałami po tej konferencji postanowili poświęcić go Jego pamięci.

Wrzesień 2015

${ }^{20}$ P. Piotrowski, Agorafilia..., s. 272. 